Marquette University

e-Publications@Marquette

College of Education Faculty Research and

Publications

Education, College of

$10-1-2007$

\title{
The Presence and Possibility of Moral Sensibility in Beginning Pre-Service Teachers
}

Sharon Chubbuck

Marquette University, sharon.chubbuck@marquette.edu

TerryJ. Burant

Marquette University, teresa.j.burant@marquette.edu

Joan Whipp

Marquette University, joan.whipp@marquette.edu

Accepted version. Ethics and Education, Vol. 2, No. 2 (October 2007): 109-130. DOI. (C) 2007 Taylor \& Francis. Used with permission. 


\section{The presence and possibility of moral sensibility in beginning pre-service teachers}

Authors: Sharon M. Chubbuck*, Terry J. Burant and Joan L. Whipp: Marquette University, USA

Abstract: This paper presents research on the moral sensibility of six pre-service teachers in an undergraduate teacher education program. Using their reflective writing across their first two semesters of coursework as well as focus group interviews in their third semester as sources of data, the paper identifies and describes three distinctive types of moral sensibility and examines ways in which moral sensibility interacts with experiences in teacher education. Suggestions for explicitly incorporating the moral in pre-service teacher education are presented.

In current times, when teaching in the United States and elsewhere is increasingly framed in the language of meeting objective learning outcomes or standards, we would do well to remember that teaching is ultimately a moral practice (Hansen, 2001b) and has been considered as such for a very long time. Regardless of the specific historical moment and political context, teaching occurs in a moral relationship between those who teach and those who learn. Given this moral relationship, conceptualizing teaching as largely a matter of knowledge and specific teaching skills is far too narrow; as Hansen (2001a) argues, teachers should also be concerned with 'fueling the human flourishing' (p. 44) of their students or, as Fallona (2000) states, developing in them to their fullest capacity 'the qualities that make life excellent or admirable' ( $p$. 681). Considering teaching from a moral point of view, philosophers, educators and researchers throughout history have recognized that teachers' personal qualities, personality variables, virtues, values and commitments (see Gage, 1963; Getzels and Jackson, 1963), and the ways in which these are expressed in actions, conduct, manner (Fenstermacher, 1992) and style (Jackson et al., 1993) are critical factors in learning.

Put another way, 'who teachers are is often decisive for what students learn or fail to learn in the classroom' (Hansen, 2001b, p. 837). To examine 'who teachers are', or in our case more accurately, who pre-service teachers are, we draw from Hansen's description (2001a) of moral sensibility as an orientation of attentiveness to students and to the profession of teaching. According to Hansen (2001a), a moral sensibility, reflected in both thought and emotion and apparent in the 'way in which a teacher thinks and acts' (p. 33; emphasis in original), connects

1 Chubbuck, Burant, \& Whipp 
both who a teacher is as well as his/her conduct 'under a unifying outlook or orientation' (p. 39) towards every aspect of the profession. In other words, a moral sensibility is an orientation towards the student and the profession that serves as the foundation of teacher thought and action.

Although the current discourse of assessment in the United States frequently sidesteps consideration of the moral, recent debate over defining, identifying and assessing teacher dispositions, ironically, has prompted a shift in that direction. In a battle between the field of teacher education and the popular press, teacher educators have been accused of using 'dispositions' as political litmus tests for entrance into teacher education programs and as cause to remove good teachers from classrooms (Gershman, 2005; Leo, 2005; Will, 2006). Concurrently, two significant US organizations of teacher educators, the National Council of Accreditation in Teacher Education (NCATE) (Wise, 2005, 2006) and the American Association of Colleges for Teacher Education (AACTE) (Sockett, 2006), have attempted to bring clarity to the process. That clarity includes increasing attention to the moral nature of teaching (Hansen, 2000; Sockett, 2006; Burant et al., forthcoming), making visible a critical aspect of teaching and school life that typically escapes notice.

In the midst of this increased attention, however, significant empirical work on the moral dimension of teaching remains to be done. Existing work has focused either on assessment of moral development through measuring and observing moral reasoning among teacher education students (Oser, 1993) or on describing the moral qualities exhibited either by in-service teachers or pre-service teachers well advanced in their program of study (see e.g. Ball and Wilson, 1996; Yost, 1997; Fallona, 2000). Exploration of the nature of the moral sensibility that pre-service teachers bring with them at the start of their program and how this sensibility intersects with their continuing development as pre-professionals has received insufficient empirical attention. Such research is needed to help teacher educators become more attentive, strategic and deliberate in their early efforts to nurture moral sensibility in pre-service teachers. For this reason, we chose to study the moral sensibility of pre-service teachers across the first three semesters of their undergraduate teacher education program, foregrounding their voices in an effort to answer these research questions:

1. What moral qualities emerge in the reflective writing and speaking of pre-service teachers in the early stages of their preparation and in what ways do they cohere to form a unifying moral sensibility?

2 Chubbuck, Burant, \& Whipp 
2. In what ways do the components of a teacher preparation program activate and nurture pre-service teachers' moral sensibility?

3. In what ways do the individual moral qualities that comprise pre-service teachers' moral sensibility affect their experience of the teacher preparation program?

\section{Theoretical framework}

At the outset, it is important to note that considering the moral dimension of teaching can often raise misconceptions. First, in this paper, the term 'moral' in the context of education is neither a matter of an added-on character-building curriculum nor does it indicate a prescribed set of personal values that can often be at odds with sets of values prescribed by others (Hansen, 2001b). Rather, we view the moral as an ethical manner of being and acting in the world with a constant awareness that one's knowledge and one's actions based on knowledge interact in the social world with significant consequences for others (Hansen, 2006). (Though moral and ethical are not identical in meaning, we see them as significantly related: Burant et al., forthcoming). Given that teaching is both a distinct practice with 'its own characteristic set of responsibilities and obligations' (Hansen, 2001a, p. 842), as well as a tradition 'symboliz[ing] a dialogue across human generations' (2001b, p. 9), teaching can be considered a unique, specific manner of being and acting in the world with an awareness of consequences. In this uniqueness, the role and person of a teacher have an ineliminably moral dimension.

Second, moral sensibility, or the way in which teachers attend to their work, is not restricted to the outcome of teaching alone. Rather, moral sensibility underlies, prompts and permeates the entire practice, including both the means and the end. The moral is made visible in the 'manner of a teacher' (Fenstermacher, 1992, p. 97) in all her or his relations to knowledge and to students that occur in the day-to-day practice of teaching. A moral sensibility is not solely determined by the quality of the end-product of teaching. Rather, teachers are constantly engaged morally as well as intellectually in the totality of their practice (Ball and Wilson, 1996). Far from being a technical, value-free process that serves as a means to a value-laden end, the moral aspects of the teaching process are integrally connected to the process of student learning and as significant in it as any specifiable product or output (Hansen, 2001b).

In fact, the moral dimension is so foundational and pervasive in classrooms and in the work of teachers that it often escapes notice. As with other nebulous and omnipresent constructs-like culture, for example - the apparent invisibility of the moral aspects of teaching elevates the importance of consciously attending to and trying to understand them. As 
Gudmundsdóttir (1990) argues, 'Value-laden impressions...frame a teacher's personal curriculum - the most hidden and least studied of all school curricula, yet it is the slice of...education that is most likely to remain with the student' (p. 47). In the current political landscape in the United States, where a technocratic view of teaching as a delivery system of knowledge is intensifying, failure to attend to the moral nature of teaching is even more likely.

Attention to the moral dimension of teaching has a long history with deep philosophical roots as well as more recent influences from developmental psychology, feminist theory, and theory and research specific to the teaching profession (Goodlad et al., 1990; Jackson et al., 1993; Oser, 1994; Hansen, 2001a, 2001b). One body of work attempts to identify moral qualities important in teaching. This work extends back to Aristotle's ethical philosophy (Aristotle, 1985), in which he derived character qualities from analysis of individuals in his own community and time period; these character qualities included virtues like truthfulness, generosity, wit, magnanimity and others. This virtue-centered approach is apparent in similar lists of virtues identified by a wide range of more recent educational philosophers and theorists: open-mindedness, wholeheartedness and intellectual responsibility (Dewey, 1964); straightforwardness, simplicity, spontaneity, naiveté, open-mindedness and open-heartedness, integrity of purpose, responsibility and seriousness (Hansen, 2001a); humility, lovingness, courage, patient impatience and a joy in living (Freire, 1998); persistence, caring, personal responsibility, love of learning, courage, confidence, reflectivity linked to action and humble admission of fallibility (Haberman, 1996); and self-knowledge, integrity, wisdom, courage, temperance, justice, open-mindedness, receptivity, relatedness and responsiveness (Sockett, 2006). The wide-ranging variety of these lists illustrates the complexity of identifying specific moral virtues as well the need for more focused attention on the moral dimension.

Drawing from both the Kantian idea of the moral imperative and John Stuart Mills's more utilitarian, consequentialist philosophy (Noddings, 1994), another line of theory and research has focused on moral reasoning and the teaching behaviors that may (or may not) result from such reasoning (Kohlberg, 1984; Oser, 1993; Chang, 1994; Rest, 1994). These efforts, with their focus on moral development as measured in moral reasoning, often fail to acknowledge the nature of the underlying moral sensibility or orientation that makes such reasoning possible (Burant et al., forthcoming). For example, feminist theorists criticized this understanding of moral development for ignoring gender differences and thus failing to acknowledge the underpinning role of a relational, caring ethic in moral sensibility (Noddings, 1994).

Much recent writing on the moral dimension of teaching has been conceptual, calling for

\section{Chubbuck, Burant, \& Whipp}


the identification of moral qualities in teaching and advocating various programs (Beyer, 1997; Campbell, 1997; Luckowski, 1997; Joseph, 2000) or strategies to enhance moral development of teachers (Hamberger and Moore, 1997). Some have called upon the teaching profession to establish a professional code of ethics (Ungaretti et al., 1997; Burant et al., forthcoming). Research on the moral dimension of teacher development has focused primarily on identifying moral qualities among teachers in later stages of their development-student teaching or beyond-rather than in the early stages of pre-service teacher development. Ball and Wilson (1996), for example, analyzed their own teaching practice to demonstrate the link between intellectual and moral aspects of teaching. Similarly, Fallona (2000) examined virtues as demonstrated by three practicing middle school teachers, using Fenstermacher's (1992) description of 'manner', which he explains as 'the moral character of the teacher' (Fenstermacher, 1990, p. 134) that is visible in the teacher's interactions with others. Yost (1997) studied 14 teacher education graduates' attitudes, evaluations and practices upon completion of their program.

Research on the moral sensibility of pre-service teachers beginning their programs is limited; this lack is problematic in light of what we know about the importance of prior knowledge and beliefs in learning. When encountering new information and experiences, learners use their prior beliefs, often unconsciously, as filters for incoming concepts (Abelson, 1979; Kagan, 1992; Pajares, 1992; Richardson, 1996). Prior beliefs also function as interpreters, framing new experiences and information in congruence with the old. In this synthesizing process, aspects of both the old and the new are changed. As Hollingsworth (1989) demonstrated, in her study of cognitive change in pre-service teachers, their 'preprogram beliefs about teaching might interact dynamically with both program content and classroom opportunities' (p. 168). Though moral sensibility cannot be simplistically equated with propositional beliefs about teaching (Burant et al., forthcoming), the theory may still be applicable. The moral sensibility that pre-service teachers bring to their teacher education programs will very likely interact with their learning experiences in significant ways. With this in mind, we researched the speech and writing of pre-service teachers for evidence of specific qualities or virtues that comprise pre-service teachers' moral sensibility, seeking to understand how moral sensibility interacts with their experiences in early teacher education courses. In other words, we wanted to see if we could indeed 'see' and 'hear' moral sensibility and understand how it might be at work in the ways in which pre-service teachers make sense of teacher education.

\section{Chubbuck, Burant, \& Whipp}




\section{Methodology}

To foreground the voices and experiences of our pre-service teachers, we utilized a naturalistic, descriptive method of inquiry (Lincoln and Guba, 1985) to surface issues that might warrant future attention, using a small group of students as case-study (Stake, 1995) informants over an 18-month period. We addressed the following research questions:

1. What moral qualities emerge in the reflective writing and speaking of pre-service teachers in the early stages of their preparation and in what ways do they cohere to form a unifying moral sensibility?

2. In what ways do the components of a teacher preparation program activate and nurture pre-service teachers' moral sensibility in the early stages of their preparation?

3. In what ways do the individual moral qualities that comprise pre-service teachers' moral sensibility affect their experience in a teacher preparation program?

\section{Context}

This study was conducted at a mid-sized, urban Jesuit university in a teacher education program that emphasizes social justice in teaching, and offers a liberal arts academic program for all majors. The undergraduate pre-service teachers, predominantly white (90\%) and under 22 years of age, complete fieldwork and student teaching primarily in racially and culturally diverse urban schools. Their first education course (taught by the second author of this paper) introduces the history and purpose of education in the United States, focusing on schooling issues related to cultural and racial diversity and engaging pre-service teachers in service learning in informal urban educational settings such as after-school tutoring programs. The second education course (taught by the first author) expands on these issues and involves researching and debating schooling policies, such as bilingual education, testing and tracking, and special education, using race, class and gender as interpretative lenses. Additional courses and related field experiences that follow include human development, learning and assessment, content methods and literacy courses, and student teaching.

\section{Participants}

Six pre-service teachers were selected as participants. Selection criteria included: (1) entrance into the teacher education program; (2) enrollment in the first course in spring 2005; (3) enrollment in the program's second course in fall 2005; (4) consent to have all written coursework included as data; and (5) consent and availability for a focus group interview in spring 2006. A total of 24 pre-service teachers met the first three criteria; 20 of those agreed to

\section{Chubbuck, Burant, \& Whipp}


have their written work included as data. Of those 20, six (one female and five males, all white and aged 20-21 years of age) also agreed to participate in and were able to schedule a focus group interview, thus forming the case-study participants. All were secondary majors: five were social studies majors and one a mathematics major (see Table 1). Due to the constraints and logistics of the selection criteria, this group clearly does not represent a balanced sample of those enrolled in the teacher education program, in terms of content area major, elementary/secondary focus, race or gender. This presents a limitation on the findings as the participants' responses may be linked to these factors. However, the research questions and the accompanying interview questions and writing prompts were constructed with a generic pre-service teacher profile in mind; that is, they were meant to be applicable to pre-service teachers of any major and teaching field.

\section{Data collection and analysis}

Data sources included six reflective writing assignments (one major reflective paper from the first course and five shorter reflective journals from the second course) and a 90-minute focus group interview conducted after the second course. The written assignments elicited responses on a variety of topics, including the participants' thoughts on their personal sense of calling to the profession of teaching, the dispositions of successful teachers, the nature of socially just teaching and their personal responses to the content of the courses. The semi-structured focus group interviews (audio taped and transcribed) asked open-ended questions to elicit participants' understandings of their experiences in the first two courses in the program. The six participants were divided, primarily based on scheduling availability, into one group of four and one group of two. Graduate student research assistants conducted the interviews during the students' third semester in the program when all had completed the first two courses and were enrolled in methods courses and associated field experiences.

Data were analyzed in several iterations of individual and collaborative coding of all written texts and transcriptions; analytic techniques were applied at both individual and cross-case levels (Patton, 1990; Yin, 1994; Stake, 1995). We first independently coded all data following open-coding techniques (Strauss and Corbin, 1990), looking for any statements that seemed to indicate moral qualities indicative of moral sensibility, a process clearly informed by the literature we had read in preparation for the project. We then met to determine the coding categories as they related to our research questions, identifying many of the same categories of moral qualities seen in the literature as well as others unique to our participants. These initial coding categories included responsibility for individuals, fairness, compassion, responsibility for 
societal issues, communitarian perspective, an orientation towards action, openness to complexity, reflectivity and humility. Based on these agreed-upon categories, we revisited all the data individually for a second round of coding and then collaboratively discussed any differences in coding until we reached consensus among all three researchers that a given statement reflected a specific example of a particular moral quality. We continued this refining process of independent/collaborative coding, eventually charting evidence of each student's moral qualities, references to personal background experiences and aspects of the courses, and any patterns and connections among the categories.

Some of the participants were clearly more talkative and articulate in their responses, raising the possibility that our identification of a particular moral quality as strong in a participant might, in fact, simply reflect greater verbal skills and loquaciousness than actual presence of the moral quality. In order to be sure we were identifying the presence of indicators of moral qualities rather than number of words and skill of articulation, we counted the total number of coded items for all moral qualities and gave each equal weight, whether one brief mention or a lengthy paragraph. We then calculated what percentage of participants' comments reflected each of the moral qualities that emerged from our coding process. These percentages were compared across cases to verify which students were strongest in each of the categories, as well as within cases to determine what percentage of their comments reflected each specific moral quality. These percentages were congruent with our qualitative findings, indicating that while an individual student's verbal skills may have appeared to create a stronger impression, the analysis was consistent regardless of the participant's verbal skill. We also recognized that the participant's manner of speaking and writing indicated a qualitative level of passionate connection to certain moral qualities that might, or might not, parallel the number of times the quality was mentioned. We noted those passionate connections in our qualitative analysis of the interaction of moral qualities with experiences in the teacher education program.

Finally, we looked at the patterns or profiles of moral qualities exhibited in each participant's case in search of the more 'unified outlook or orientation' that Hansen (2001a) terms 'moral sensibility'. We paid close attention to the places in the data where the participants' words indicated the fusing of thought and emotion (Hansen, 2001a) in specific moral qualities; we examined how these cohered around or contributed to a more unified moral sensibility towards teaching; and we explored the interaction among these moral elements and components of the teacher education program. In effect, we looked at the kinds of things these pre-service teachers attended to and what moral frameworks they used in focusing their attention and structuring their 
response, at both cross-case and within-case levels of analysis.

\section{Findings}

The specific moral qualities seen in the data across cases revealed three coherent categories of moral sensibility that the pre-service teachers appeared to bring with them to their teacher education program: an individually focused sensibility (including responsibility for individuals, fairness, compassion); a socially focused sensibility (including responsibility for societal issues, communitarian perspective, an orientation towards societal level action); and an intellectually focused sensibility (including openness to complexity, reflectivity, humility) (Table 2). Here we, first, describe each of the aforementioned sensibilities in greater detail using examples from across the cases. Then we identify the various aspects of the teacher education program that appeared to surface, interact with and strengthen those varied moral sensibilities. Finally, we returned to the individual cases to examine how, for each participant, a passionate commitment to one or more of the individual moral qualities interacted reciprocally with program components to influence the nature of the meaning the participants assigned to program experiences.

\section{Three types of moral sensibility seen in cross-case analysis}

Individually focused moral sensibility

The individually focused moral sensibility includes fairness, compassion, and a strong sense of responsibility to the individual. This relational moral orientation mirrors much of Noddings's $(1984,2005)$ notion of ethical caring. According to Noddings, the caring teacher first attends to and sees students in a positive light and then compassionately, actively and fairly responds to their needs. Far from being mere sentiment, Noddings's ethic of care orients the teacher to the growth and well-being of others and is expressed in actions towards individual students. To some extent, this individually focused moral sensibility emerged in all six of these aspiring teachers' writing and speaking. However, two case-study participants were considerably higher in this category: Luke, with more than half of his comments in this category, and Brian, with almost half of his comments located here. Charles demonstrated the next highest, with almost one-third of his comments reflecting this moral orientation.

These three participants' expressions of an individually focused moral sensibility included compassionately relating to individual students by seeing the good in each one, hearing 'the stories behind who they are' and making their students 'feel like the center of attention every time [l] talk to [them]' (Charles). Brian, the participant with the strongest expression of compassion, wanted to develop personal relationships with students, describing his desire to make his 
'classroom feel like a family'. He also voiced a need for fairness that he characterized as equal treatment in areas like grading and in being inclusive, saying:

Teachers can't be biased in any way and you have to give all the kids the same chance.

Of all the participants, Luke demonstrated the strongest sense of fairness for the individual, with almost a quarter of his total coded comments expressing this moral quality alone. An example of this quality is seen in Luke's repeated references to an experience from his childhood when he saw an African American student falsely accused of stealing a bicycle instead of his white friend, the actual culprit. Unable to let the African American student remain unfairly accused, Luke eventually told on his white friend. In his application of fairness to teaching, Luke stated that a teacher should provide equally challenging learning opportunities to all, present unbiased views of issues, and 'jump at every opportunity to assist students'. He claimed that such work is 'not to be taken lightly' and requires long hours; when he spoke of his future as a teacher, he described how he wanted:

to come home tired [every day], knowing I helped as many kids as I possibly could.

He was outraged when he saw teachers he believed were treating their students unfairly, stating:

I don't know what's going through people's minds!

\section{Societally focused moral sensibility}

The societally focused moral sensibility includes a sense of responsibility for the common good at a societal level, a communitarian identity and a willingness to act at a societal level based on one's convictions. This moral sensibility most closely reflects critical pedagogy, with its focus on 'iniquitous power relations' (Giroux, 1997, p. 313) operating in societal institutions, including schools, to reproduce highly stratified, class-based divisions marked by significant material inequities. Pre-service teachers who embrace this societally focused moral sensibility recognize that inequitable learning experiences significantly derive from societal-level inequities; they actively analyze and engage those 'politically contested spaces' (Kincheloe, 2005, p. 2) of school and society, seek to transform structural inequities, and speak of empowering their students to effect similar change in their own lives. Participants strong in this moral sensibility 
also recognized the importance of teachers attending to the needs of individual students; however, their fusion of thought and emotion clearly cohered around identifying inequity as the product of systemic and structural discrimination, rather than simply as individually expressed discrimination or unfairness directed towards students. Frank was strongest in this moral sensibility, with almost half of his comments falling into this category. Dominic and Sophia were also strong, with approximately one-third of their comments reflecting this socially focused moral sensibility.

Frank, Dominic and Sophia believed that teaching warranted attention to both individual students and the circumstances of society, claiming that a concern for individual students quite reasonably led to addressing the problems of the larger society in which the students live. For example, Sophia stated that in her teaching she wanted to:

better not only the students, but the society around them.

Similarly, Dominic wanted to:

[not only help a student] perform at a higher level...[by working] hard to amend the problem at hand, but...[working] even harder to discover the root of the problem.

Dominic described a heated family conversation that occurred during the second course that solidified his societal perspective. In a discussion about 'the things [he] learned in [the second course about institutional racism], the [expletive] hit the fan...and almost got [him] kicked out of the house that night'; his family's reaction deepened both his understanding of the inequities produced by larger social systems and the need for collective, systemic response. As he described:

There's a group of people who...this underlying racism affects, and there's a group of people who are completely unaware of it...It makes you think this issue is so massive that in order to change things, it really has to be on this huge, national, revolutionary [level].

All three understood that addressing societal-level inequity would require a collective response. Addressing issues of educational injustice 'supersedes what one individual can do' (Sophia), and requires teachers 'to work together to make a social change' (Frank). Implicit in their recognition for collective response was an orientation towards activism. Frank, who had the strongest desire to work for social change, identified his multiculturally diverse high school as 11 Chubbuck, Burant, \& Whipp 
influencing his commitment to activism, including his participation in a student-led protest against the Iraq war. He spoke fervently about his continuing passion for activism to address inequity:

You better believe I will be out there marching, protesting, striking, walking, rioting for causes that I think are important to the betterment of society...I want to really rally up the citizens and open their eyes to what's going on...I certainly want to be an activist.

Dominic and Sophia often focused their vision of activism on images of themselves using class discussions and activities to teach their future students to critically analyze events and institutions and encourage responsibility at the societal level. Sophia's highest goal for 'my students [is to see] the importance of change and the importance of taking part in that change', a goal reminiscent of the high school class where she:

looked at social problems in our own community and [helped] figure out what we could to do alleviate situations [at a societal level].

Dominic saw this goal- to teach students 'how to be conscientious citizens' and to 'show kids how to work for justice in their own backyards'-as a moral obligation, claiming that:

I cannot not see myself doing this. It would be shameful not to do this.

\section{Intellectually focused moral sensibility}

The third moral orientation, an intellectually focused sensibility, brings together humility, openness to complexity and multiple perspectives, and reflectivity. Rather than reflecting self-effacement, humility is described by Hansen (2001a) and Freire (1998) as an awareness of one's own limitations with a consequent willingness to lay down one's ideologies when faced with situations and ideas that demand thought or provoke new questions. Openness to complexity, akin to Dewey's notion of wholeheartedness (1964), marries persistent searching for new perspectives and a willing suspension of prior judgment about issues in order to more fully grasp the bigger picture with its uncertainties and complexities. This intellectually orientated sensibility also includes reflectivity, described by Hansen (2001a) as 'the ability to stand back from the scene at certain moments in order to discern the issues at stake, to appreciate the differences in point of view that may be involved' (p. 33). Three participants-Sophia, Charles and Dominic_revealed high concentrations of these intellectual qualities and all explicitly valued knowledge as an ideal worth pursuing.

In Dominic's case, a spirit of unabashed humility permeated his writing and interview 
comments. For example, he repeatedly described with great appreciation how he was becoming 'aware of [his own] ignorance' throughout his teacher education courses and learning to 'push pause and think'. The frequent, heated classroom debates in the second course in the teacher education program regularly prompted this experience for Dominic, where:

every day you find out that you have no idea what you are talking about...all of a sudden you'd find yourself at square 1 trying to re-evaluate what your beliefs actually are.

Sophia, similarly, embraced humility when she compared her budding understandings of racism and inequities in education with the sophistication of the perspectives of $\mathrm{K}-12$ students in her field placements:

These kids see it [institutional racism], and I came to college and I was, like, 'No, race is fine in America'. At 18! And these kids are 12!

Sophia questioned why:

it took me this long to realize in my 21 years that there's this magnitude of problems.

Her openness to complexity and her drive to unearth multiple perspectives reflected Sophia's exuberance and passion for learning, no matter what the issue. Charles was similarly strong in openness, in large part, due to a high school political science course that opened his eyes to the importance of an informed, politically active citizenry and sparked his own political activism and ambitions. He was fervently and consistently interested in seeing all sides of political debate about schooling and the role of schools and government in tackling social problems. All three participants expressed a propensity for reflection. Charles described:

thinking about [course content and discussions] over break...mulling over this whole education thing.

He revisited his confusions and questions in prayer. Similarly, Dominic reflected on:

the juxtaposition between going to my field placement [in a central city school] and then going home for...spring break and I realized how much how much of a bubble I had gone to school in.

\section{Effect of significant program components}

Each of our participants clearly brought a strong moral sensibility to the program. Their 13 Chubbuck, Burant, \& Whipp 
references to experiences prior to entering the teacher education program-as in Luke's story of the stolen bicycle and the falsely accused African American student; Frank's exposure to activism in the multicultural diversity in his high school; and Charles's and Sophia's experiences in high school social studies classes-illustrate that these moral qualities were present in the pre-service teachers as they came to their teacher education program. Yet the content and experiences of their early teacher education courses also appeared to surface, interact with and strengthen the pre-service teachers' prior moral sensibility.

Certainly, the informational content sparked the participants' moral responses as they encountered facts and perspectives on educational issues that challenged their previous thinking. For example, Charles described how the content of the second course, in particular, the research he was required to do in order to write a paper and create a website, increased his intellectual openness when he:

had to delve into what's behind policy, what's behind personal stories. It really makes you develop an appreciation for complexity.

Sophia stated that:

I feel like in half a semester I have learned things [about societal-level inequities] that I should have learned quite a long time ago.

Dominic demonstrated the effects of course content as he repeatedly referenced a metaphor used in his second education course. He said that this metaphor, which contrasted saving individual 'babies drowning in a river' with 'going upstream to see who is throwing them in', helped him conceptualize the need to move beyond individual responses to include societal-level responses to inequity as well.

Beyond academic content, however, the participants spoke frequently of more interpersonal experiences that appeared to be both linked to and influential in prompting the expression of moral sensibility. Knowledge and activities connected to real people, evoking emotional as well as intellectual responses from the participants, emerged in the data regularly. For example, all six participants either specifically mentioned or nodded in agreement over the significance of stories of real teachers, such as Dreamkeepers (Ladson-Billings, 1994) and Holler if you hear me (Michie, 1999). These texts, read in the first class, provided models for how care, compassion and fairness for individual students could be practically expressed. Field placements and co-curricular experiences (such as service learning and participation in community events), which also provided connections to real students and teaching contexts, 14 Chubbuck, Burant, \& Whipp 
were frequently linked to expression of moral sensibility. Frank, Sophia, Dominic, Brian and Luke all commented on the powerful effects of their involvement in various tutoring programs, including increased empathy (Brian), focus on individual students' needs (Sophia) and excitement over helping a child to grow academically with positive future implications (Dominic and Frank).

Equally, if not more prevalent in the data were the participants' comments about the effects of processing course content through discussion, both inside and outside of classes. All six participants commented on the value of role-playing, small group interactions, sharing stories and/or extended and structured discussions, especially in their second class, in helping them clarify and expand their own thinking and see multiple perspectives. The power of specific classroom interactions was seen in frequent abbreviated references to them in the interviews: 'Remember the [coffee shop/role-play] discussion on the day we had banana bread?' and 'Remember the time we filled out [and then talked about] those identity charts?' Participants identified several elements they believed added to the power of these classroom activities. According to Luke, there was something valuable about having these discussions in the context of a committed group of future teachers:

There is something in us, the fact that everybody in the room [during the second class] wanted to be a teacher and wanted to help each other.

And Dominic identified the value of non-traditional ways of interacting together around the content, for example, describing the role-play activities as:

so much more engaging than kind of the lecture that a lot of education classes are characterized by...I think once you break out of that mold [of lecturing] you, kind of, have discussion like that that stay in your mind.

Finally, the instructor's role in establishing an atmosphere open to multiple perspectives was important, as seen in Sophia's comment:

[The professor] also made a really open atmosphere so everyone was very comfortable sharing their opinions which is good...I think the more open people are to sharing their opinions, the more you can delve into complex issues and it really opens your eyes.

\section{Interaction of within-case moral qualities and program components}

It is not surprising that the moral sensibility of each pre-service teacher was both activated and strengthened by informational content, personal encounters in field and service 
experiences, and opportunities for processing each of these. The data, however, indicated that particular moral qualities within each case interacted reciprocally with program components in interesting ways. Those moral qualities most passionately embraced by each participant (as indicated by the number of coded items as well as the strength of language used by the pre-service teacher when speaking or writing about a specific item) served as focusing and interpretive lenses on what they were experiencing, in much the same way that beliefs shape one's interpretation of experiences (Pajares, 1992). At times enhancing and at other times hindering their engagement with the components of the teacher education program, the elements of the pre-service teachers' moral sensibilities were seldom neutral.

\section{Luke, Brian and Charles}

Luke's most passionate commitment was to fairness, followed by responsibility for the individual and reflection. His consistent and passionate return to the individual focus, particularly to the importance of fairness for all students, was striking. He was adamantly committed to being a dedicated teacher who would work tirelessly for the good of his students, yet his passionate focus on fairness for the individual seemed to prevent the openness needed to process and incorporate course content that suggested interpretations of students' learning experiences derived from structural, societal inequities. When interpreting ideas and events, he almost always used an individualistic lens, with little evidence of any societal-level interpretation.

Though Brian was strongest in an individually focused moral sensibility, his most significant single moral quality was openness, followed by compassion, responsibility to the individual and fairness. Components of the teacher education program that had the greatest effect on Brian were his field experiences and co-curricular experiences, where he demonstrated an open and compassionate response to the cultures and people he encountered. He commented several times on how attending an African American step-show was significant in opening his mind to wider cultural perspectives and on how tutoring a young African American student increased his empathy for those experiencing racial stereotyping. His openness and compassion, however, coupled with his sense of responsibility for the individual, may have kept him from being equally open to more societally focused concepts and interpretive models presented in the courses. Numerous times, as he ventured into consideration of a societal interpretation of inequity, he voiced caution over offending students or administrators. He was concerned about 'maintaining control and not crossing any boundaries' that might be 'offensive to anyone'. His compassion seemed to be the source of some of this caution, as he was deeply concerned about making statements he feared might offend his students. Though open and 
compassionate towards diverse cultures and individuals, his routinely cautious posture limited the likelihood that he might develop more of a societally focused moral sensibility.

Charles's strongest individual moral components were openness to complexity and reflection, followed by responsibility to the individual. He clearly valued exposure to knowledge and multiple perspectives as seen in his statement about 'delving[ing] into what's behind policy, what's behind personal stories' to 'develop an appreciation for complexity'. Charles's openness was directly related to his passionate commitment to conservative political interests, evidenced by his own political activity on campus and aspirations for a future in politics. That political commitment, coupled with his strong perspective of individual responsibility, appeared to limit his openness to a societally focused interpretation of inequity. For example, his thoughts about seeing all sides of issues were often framed as a counter-narrative to hearing about 'social justice all the time' and equating it with a 'liberal political view'. In Charles's own words:

[my] passion for political issues sometimes gets in the way of my ability to listen carefully to the perspectives of others.

While Charles was clearly committed to intellectual growth, his political passions in conjunction with his individualistic focus may have hindered the development of a societally focused moral sensibility.

Frank, Dominic and Sophia

Frank's strongest, most passionate specific moral components were responsibility at a societal level, activism to address societal injustice, and openness to the multiple perspectives of a diverse society. As he encountered the course content, particularly issues of injustice, he responded with exuberant statements:

I want to go into those city schools and do everything in my power to change things.

Frank frequently used the societal-level lens with an activist orientation to interpret and respond to new content information and his field experiences at his after-school tutoring program. Reflectivity, however, was quite low in Frank's writing and interview data. This lack of reflection, coupled with his unbridled enthusiasm for activism, may have contributed to his apparent inability to focus his activism on specific areas of concern as seen in his comment:

I do care about these social justice issues. I don't really want to pick and 
choose one. I just want to tackle them all!

Dominic's strongest moral qualities were reflection and responsibility at a societal level, followed by openness and responsibility to the individual. His most striking moral quality, however, was seen in his passionate articulation of the quality we labeled humility. Though he didn't mention humility as frequently as other moral qualities, each time Dominic spoke of situations where he discovered 'my own ignorance', his words and animated tone demonstrated his fascination with and passionate commitment to this process of growth:

To become aware of your own ignorance is this really profound feeling -it is!

As he encountered challenging material in the course, particularly issues of structural inequality such as white privilege, he struggled, but he most often framed the struggle in a positive light, laying down his own ideas in order to consider the new perspectives being presented:

It is like [the first course] kicked you in the face, and then like [the second course] is like going to the doctor's office afterwards...you go into that [first] class and you come out thinking that, 'I'm white, I have no culture, and I'm racist, but I never realized it'.

In the second class, it is like:

All right. Sit down, now, and let's talk about it.

The combination of the humility Dominic displayed in his willingness to 'sit down and talk about it' and his openness and reflection worked together to support his engagement with the content of the program and his ability to adopt various interpretative lenses, including a grasp of inequity at a societal level.

Sophia's two strongest moral components were openness and reflection-she consistently appeared hungry to learn—followed by responsibility at a societal level and compassion. Responsibility to the individual and fairness were low. As she encountered the various components of the program—course content, field experiences and readings—she embraced the knowledge, often wondering why she hadn't learned it sooner:

I feel like in half a semester I have learned things [about societal-level inequities] that I should have learned quite a long time ago.

18 Chubbuck, Burant, \& Whipp 
Discussion with others, however, seemed particularly significant for her; in these circumstances, her openness and compassion were enlivened and developed. She described how, in the first course, she was:

Very stubborn in thinking like my own views [about things like institutional racism], like I would hear other people's opinions and...I'd obviously listen to them, but I didn't absorb them.

Her openness expanded in the second course, in the context of an increased interpersonal connection to peers '[where] being so close to so many people in the class', as well as realizing that:

this is what my friends and what my future colleagues are saying [made me think] that I should be taking this in and examining it more.

In another example, Sophia told of a conversation with an African American college student who described her social experience on campus as vastly different from Sophia's, prompting her to reflect on the demographics of the university and both individual- and societal-level concerns about race. This girl, she said:

opened my eyes to this not being a diverse campus...It made me realize that not everyone has the same experience that I do.

Sophia was clearly open to learning and her compassion for others seemed to increase the new knowledge and experience available to her.

In summary, the pre-service teachers each came to their learning with existing moral sensibility—individual, societal and intellectual-and clustered within these sensibilities, each came with specific, individual moral qualities more prominent than others. These moral sensibilities, specific moral qualities, and the interaction of each with components of a teacher education program have significant implication for teacher education.

\section{Implications}

Amid recent efforts in teacher education programs in the United States to define, develop and assess dispositions of teacher candidates, the deceptively simple reality that teacher candidates do not come to their programs as a tabula rasa, devoid of moral orientations, is easily overlooked. Our examination of moral sensibility in beginning pre-service teachers, first of all, 
affirms that teacher candidates bring with them existing moral orientations or sensibilities that fuse reason and emotion and are apparent in the 'way in which a teacher thinks and acts' (Hansen, 2001a, p. 33). These moral sensibilities, drawn from and continuously shaped by a wide range of sources-from faith to family, personal relationships to pedagogy, schooling to employment, politics to passions-provide teacher candidates with substantial moral underpinnings and guides for their conduct. Bidden or unbidden, acknowledged or unacknowledged, moral sensibility is integral to pre-service teachers in every moment of their teacher training programs.

While this reality may seem intuitively obvious, the significance lies in the possibility lost or gained when teacher educators do, or do not, acknowledge and build on the presence of moral sensibility in its constant, powerful interaction with pre-service teachers' learning. Whether studying guided reading lessons, cooperative learning strategies, or history and theories of education or engaging in reflective discussions of field experiences, teacher candidates experience the curriculum as moral, using their sensibilities to wrestle with new ideas and respond with both thought and emotion to those new ideas.

Sockett (2006) reminds us of the important pedagogical implications of seeing teacher candidates as people with moral orientations already in progress:

If we admit that a student is already grounded in some sort of moral perspective, the pedagogical task then becomes one of building on that moral grounding as the center of the teaching and learning process and, in doing so, respecting and educating the individual moral perspective of the student. (p. 10)

Our findings indicate that the pedagogical implications of responding to pre-service teachers' moral sensibility are multiple.

First, the existing moral compasses of teacher candidates can serve as powerful ports of entry to draw pre-service teachers towards greater engagement and depth with program content. Charles was compelled by the complexity of arguments. Brian was consistently moved by compassion, Dominic by the chance to grow. Acknowledging the almost constant interaction of moral sensibility with program components and looking for ways to engage pre-service teachers at those entry points can be a powerful teaching tool, stimulating varied approaches to content in teacher education. For example, a predicament in teaching practice in a field placement, such as a conflict involving a student, a parent and a teacher, could be examined from the perspectives of the three main moral orientations we saw in this study-i.e. individually, societally and 
intellectually focused. Applying an individually oriented lens to the dilemma emphasizes fairness and care for each person involved; using a societally focused perspective prompts students to see the larger context that might play a role in the conflict as well as in its possible solutions; and engaging an intellectually focused frame surfaces multiple stories and factors for consideration. Acknowledging and utilizing these varied moral orientations expands possibilities for pre-service teachers' points of engagement and understanding.

In addition to providing points of entry, however, the moral sensibility of pre-service teachers can also provide places to challenge them and stimulate further growth. Our pre-service teachers' comments indicated that some of them clearly preferred particular ways of framing the moral in their experiences; at times, these existing frameworks acted like default mechanisms and, similar to teacher beliefs (Pajares, 1992), were used to focus attention and to interpret and assign meaning to the curriculum at hand. Luke's sensitivity to fair treatment of individuals and Brian's compassionate concern over offending an individual by appearing biased towards an issue both seemed to lock them into a narrow, albeit worthy, focus for their moral energies. Frank's somewhat unreflective activism begged for more thoughtful consideration. Pre-service teachers' propensity for specific moral perspectives provides venues for challenge as all components of the teacher education program-courses, stories, discussions and field experiences-become sites where teacher candidates can theoretically see these sensibilities in action, personally examine and evaluate their own and eventually 'try on' other moral perspectives. While this approximates exercises in moral reasoning (Oser, 1993), the focus is on facilitating rather than assessing development of the moral dimension.

The 'pedagogical task' to which Sockett (2006) refers-building on these existing moral compasses-encompasses both pedagogy and curriculum in teacher education. Our findings, however, also indicate the importance of framing program components more broadly than simply cognitive mastery and evaluation of intellectual content, to include the wedding of thought and emotion (Hansen, 2001a). While no method, activity or content stood out as the most critical for engaging the moral dimension in our research, some by virtue of their more interpersonal qualities clearly prompted the engagement of participants' moral sensibility more than others. Face-to-race relationships with students in after-school tutoring programs or field placements stood out. Vivid stories about practicing teachers provided the grist for grappling with moral concerns. And throughout, discussions among peers in teacher education classes or with other college students on campus brought the moral dimension into focus, helping pre-service teachers extend their ideas and consider wider perspectives. Our participants' fusion of thought 
and emotion in these interpersonal sites seemed to spark stronger engagement with the moral dimension, and along with that, with program content.

Our research raised many questions. Are some moral qualities inherently more important than others for teacher candidates? Are some moral sensibilities harder for students to develop than others? What is the significance of our own moral sensibility as teacher educators in our daily conduct with our pre-service teachers? Will our moral sensibility, exhibited in conduct, become 'the slice of...education that is most likely to remain' with them (Gudmundsdóttir, 1990, p. 47)? And perhaps most significant of all, how will our participants' moral sensibilities be exhibited in their practice as student teachers and eventually as teachers? Clearly, more research needs to explore the questions.

Amid of these remaining questions, our study has affirmed for us the importance of foregrounding the moral dimension in education, given its pervasive presence and its continuing possibility for supporting teacher candidate learning. With Sockett (2006, p. 21), we reject the 'incoherent view that the teacher is a technician with a topping of moral dispositions' (p. 21). Rather than an add-on, a surface adornment contributing perhaps a small dose of flavor or flash, the 'development of the dispositions of character, intellect, and caring are the core of professional teaching' (Sockett, 2006, p. 21; emphasis in original). The presence of the moral dimension in all of us is a reality. The potential of the moral dimension to powerfully enhance pre-service teacher education is also a reality, one that teacher educators cannot afford to ignore.

\section{Notes}

- $\quad$ *99E Schroeder Complex, PO Box 1881, Marquette University, Milwaukee, WI 53201, USA. Email: Sharon.chubbuck@marquette.edu

\section{References}

Abelson, J. (1979) Differences between belief and knowledge systems, Cognitive Science, 3, 355-366.

Aristole (1985) Nicomachean ethics (T. Irwin, trans.) (Indianapolis, IN, Hackett).

Ball, D. L. and Wilson, S. M. (1996) Integrity in teaching: recognizing the fusion of the moral and the intellectual, American Educational Research Journal, 33(1), 155-192.

Beyer, L. E. (1997) The moral contours of teacher education, Journal of Teacher Education, 48(4), 245-254.

Burant, T. J., Chubbuck, S. M. and Whipp, J. (forthcoming) Reclaiming the moral in the dispositions debate, Journal of Teacher Education.

22 Chubbuck, Burant, \& Whipp 
Campbell, E. (1997) Connecting the ethics of teaching and moral education, Journal of Teacher Education, 48(4), 255-263.

Chang, F. (1994) School teachers' moral reasoning, in: J. Rest and D. Navaerz (Eds) Moral development in the professions (Hillsdale, NJ, Lawrence Erlbaum), 71-84.

Dewey, J. (1964) Why reflective teaching must be an educational aim, in: R. D. Archambault (Ed.) John Dewey on education (Chicago, University of Chicago Press), 313-338. (Original work published 1933.)

Fallona, C. (2000) Manner in teaching: a study in observing and interpreting teachers' moral virtues, Teaching and Teacher Education, 16, 681-695.

Fenstermacher, G. D. (1990) Some moral considerations on teaching as a profession, in: J. I. Goodlad, R. Soder and K. A. Sirotnik (Eds) The moral dimensions of teaching (San Francisco, CA, Jossey-Bass), 130-154.

Fenstermacher, J. D. (1992) The concepts of method and manner in teaching, in: J. K. Oser, J. Dick and J. Patry (Eds) Effective and responsible teaching (San Francisco, CA, Jossey-Bass), 95-108.

Freire, P. (1998) Teachers as cultural workers: letters to those who dare teach (Boulder, CO, Westview Press).

Gage, N. L. (1963) Paradigms for research on teaching, in: N. L. Gage (Ed.) Handbook of research on teaching (Chicago, American Educational Research Association), 91-141.

Gershman, J. (2005) 'Disposition' emerges as issue at Brooklyn College. Available online at: http:// www.nysun.com/article/14604 (accessed 31 May 2005).

Getzels, J. W. and Jackson, P. W. (1963) The teachers' personality and characteristics, in: N. L. Gage (Ed.) Handbook of research on teaching (Chicago, American Educational Research Association), 506-582.

Giroux, H. A. (1997) Rewriting the discourse of racial identity: towards a pedagogy and politics of whiteness, Harvard Educational Review, 67(2), 285-320.

Goodlad, J. I., Soder, R. and Sirotnik, K. (Eds) (1990) The moral dimensions of teaching (San Francisco, CA, Jossey-Bass).

Gudmundsdóttir, S. (1990) Values in pedagogical content knowledge, Journal of Teacher Education, 4(3), 44-52.

Haberman, M. (1996) Selecting and preparing culturally competent teachers for urban schools, in: J. Sikula (Ed.) Handbook of research on teacher education (2nd edn) (New York, Macmillan), 747-760.

23 Chubbuck, Burant, \& Whipp 
Hamberger, N. M. and Moore Jr, R. L. (1997) From personal to professional values:

conversations about conflicts, Journal of Teacher Education, 48(4), 301-310.

Hansen D. T. (2000) Cultivating an intellectual and moral sensibility as teachers, paper presented at Annual meeting of the American Educational Research Association, New Orleans, LA, April 2000.

Hansen, D. T. (2001a) Exploring the moral heart of teaching: toward a teacher's creed (New York, Teachers College Press).

Hansen, D. T. (2001b) Teaching as a moral activity, in: V. Richardson (Ed.) Handbook of research on teaching (4th edn) (Washington, DC, American Educational Research Association), 826-857.

Hansen, D. T. (2006) Moral knowledge as an aim of education: John Dewey, paper presented at Annual Meeting of the American Educational Research Association, San Francisco, CA, April 2000.

Hollingsworth, S. (1989) Prior beliefs and cognitive change in learning to teach, American Educational Research Journal, 26(2), 160-189.

Jackson, P. W., Boostrom, R. E. and Hansen, D. T. (1993) The moral life of schools (San Francisco, CA, Jossey-Bass).

Joseph, P. B. (2000) Teaching about 'the moral classroom': a moral lens for reflecting on practice, paper presented at Annual Meeting of the American Educational Research Association, New Orleans, LA, April 2000.

Kagan, D. M. (1992) Implications of research on teacher belief, Educational Psychologist, 27(1), 65-90.

Kincheloe, J. L. (2005) Critical pedagogy (New York, Peter Lang).

Kohlberg, L. (1984) The psychology of moral development (Vol. 2) (San Francisco, CA, Harper \& Row).

Ladson-Billings, G. (1994) The dreamkeepers (San Francisco, CA, Jossey-Bass).

Leo, J. (2005) Class(room) warriors, US News and World Report, 24 October.

Lincoln, E. and Guba, E. (1985) Naturalistic inquiry (Newbury, CA, Sage).

Luckowski, J. A. (1997) A virtue-centered approach to ethics education, Journal of Teacher Education, 48(4), 264-270.

Michie, G. (1999) Holler if you hear me: the education of a teacher and his students (New York, Teachers College Press).

Noddings, N. (1984) Caring: a feminine approach to ethics and moral education (Berkeley, CA,

24 Chubbuck, Burant, \& Whipp 
University of California Press).

Noddings, N. (1994) Philosophy of education (Boulder, CO, Westview Press).

Noddings, N. (2005) The challenge to care in schools: an alternative approach to education (2nd edn) (New York, Teachers College Press).

Oser, F. K. (1993) Trust in advance: on the professional morality of teaching, Journal of Moral Education, 22(3), 255-276.

Oser, F. K. (1994) Moral perspectives on teaching, Review of Research in Education, 20, $57-127$.

Pajares, M. F. (1992) Teachers' beliefs and educational research: cleaning up a messy construct, Review of Educational Research, 62(3), 307-332.

Patton, M. A. (1990) Qualitative evaluation and research methods (2nd edn) (Newbury Park, CA, Sage).

Rest, J. (1994) Background: theory and research, in: J. Rest and D. Navaerz (Eds) Moral development in the professions (Hillsdale, NJ, Lawrence Erlbaum), 1-26.

Richardson, V. (1996) The role of attitudes and beliefs in learning to teach, in: J. Sikula (Ed.) Handbook of research on teacher education (New York, Simon \& Schuster), 102-119.

Stake, R. E. (1995) The art of case-study research (Thousand Oaks, CA, Sage).

Strauss, A. and Corbin, J. (1990) Basics of qualitative research: grounded theory procedures and techniques (Newbury Park, CA, Sage).

Sockett, H. (2006) Character, rules and relationships, in: H. Sockett (Ed.) Teacher dispositions: building a teacher education framework of moral standards (Washington, DC, AACTE Publications), 9-25.

Ungaretti, T., Dorsey, A. G., Freeman, N. and Bologna, T. M. (1997) A teacher education ethics initiative: a collaborative response to a professional need, Journal of Teacher Education, 48(4), 271-280.

Will, G. (2006) Ed schools vs. education, Newsweek, 16 January.

Wise, A. (2005) US News and World Report: editorial opinion. October 17, 2005. Available online at: http://www.usnews.com/usnews/letters/articles/051114/14lett_5.html (accessed 25 January 2006).

Wise, A. (2006) NCATE News: Wise to Hess, Will, and Leo: February 28, 2006. Available online at: http://www.ncate.org/public/0228_postWise.asp?ch=150 (accessed 25 May 2006).

Yin, R. K. (1994) Case-study research, design and methods (2nd edn) (CASage, Newbury Park).

Yost, D. S. (1997) The moral dimensions of teaching and pre-service teachers: can moral

25 Chubbuck, Burant, \& Whipp 
dispositions be influenced? Journal of Teacher Education, 48(4), 281-292.

\section{Appendix}

Table 1

Participants

\begin{tabular}{|l|c|c|c|c|}
\hline Pseudonym & Gender & Age & Major & Race \\
\hline Sophia & F & 21 & Social Studies & White \\
\hline Dominic & M & 21 & Social Studies & White \\
\hline Charles & M & 20 & Social Studies & White \\
\hline Frank & M & 21 & Social Studies & White \\
\hline Brain & M & 21 & Mathematics & White \\
\hline Luke & M & 21 & Social Studies & White \\
\hline
\end{tabular}

Table 2

Types of moral sensibility

\begin{tabular}{|l|l|}
\hline Moral sensibility & Specific moral qualities \\
\hline Individually focused & Responsibility for individual, fairness, compassion \\
\hline Socially focused & $\begin{array}{l}\text { Responsibility for societal issues, communitarian perspective, } \\
\text { orientation towards societal-level action }\end{array}$ \\
\hline Intellectually focused & Openness to complexity, reflectivity, humility \\
\hline
\end{tabular}

